\title{
Synthesis and Crystal Structures of Benzohydroxamate-Coordinated Vanadium(V) Oxo Complexes with Aroylhydrazone Ligands
}

\author{
Shao-Song Qian, ${ }^{1}$ Xinlu Zhao, ${ }^{2}$ Jia Wang ${ }^{2}$ and Zhonglu You ${ }^{1,2, *}$ \\ ${ }^{1}$ School of Life Sciences, Shandong University of Technology, ZiBo 255049, P. R. China \\ ${ }^{2}$ Department of Chemistry and Chemical Engineering, Liaoning Normal University, Dalian 116029, P. R. China \\ *Corresponding author: E-mail: youzhonglu@lnnu.edu.cn
}

Received: 18-03-2015

\begin{abstract}
Reaction of $\left[\mathrm{VO}(\mathrm{acac})_{2}\right]$ (where acac $=$ acetylacetonate), benzohydroxamic acid (Hbha), and two similar aroylhydrazone ligands in methanol produced two benzohydroxamate-coordinated mononuclear vanadium(V) oxo complexes with general formula [VOL(bha)], where $\mathrm{L}=\mathrm{L}^{1}=N^{\prime}$-(5-bromo-2-hydroxybenzylidene)-2-fluorobenzohydrazide $\left(\mathrm{H}_{2} \mathrm{~L}^{1}\right)$, and $\mathrm{L}=\mathrm{L}^{2}=N^{\prime}$-(3-bromo-2-hydroxybenzylidene)-2-fluorobenzohydrazide $\left(\mathrm{H}_{2} \mathrm{~L}^{2}\right)$. Crystal and molecular structures of the complexes were determined by single crystal X-ray diffraction method. All of the investigated compounds were further characterized by elemental analysis, and FT-IR and UV-Vis spectroscopy. Single crystal X-ray structural studies reveal that the $\mathrm{V}$ atoms in both complexes are in octahedral coordination with the benzohydrazone ligands coordinated to the VO cores through phenolate $\mathrm{O}$, imino $\mathrm{N}$, and enolate $\mathrm{O}$ atoms, and the benzohydroxamate ligands coordinated to the VO cores through deprotonated hydroxyl $\mathrm{O}$ and carbonyl $\mathrm{O}$ atoms. Thermal stability of the complexes was studied.
\end{abstract}

Keywords: Vanadium complex; Aroylhydrazone ligand; Crystal structure; X-ray diffraction; Thermal property

\section{Introduction}

Vanadium is an essential trace element for different organisms. The increasing interest in coordination chemistry of vanadium is derived from its well-established chemical and biological functions. ${ }^{1}$ Much attention has been paid to the study of behavior and functions of vanadium in biological systems ${ }^{2}$ as well as its catalytic and pharmaceutical applications. ${ }^{3}$ Hydrazone derivatives and their metal complexes have been intensively studied for their potential applications in material and medicinal chemistry. ${ }^{4}$ These ligands can due to their facile keto-enol and the availability of several potential donor sites chelate metal atoms in versatile manners. ${ }^{5}$ In recent years, most vanadium complexes with Schiff base ligands have been proved to have insulin mimetic property. ${ }^{6}$ However, vanadium(V) complexes with<smiles>O=C(N/N=C/c1cc(Br)ccc1O)c1ccccc1F</smiles>

$\mathrm{H}_{2} \mathrm{~L}^{\prime}$

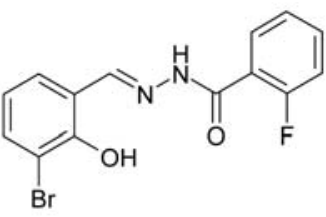

$\mathrm{H}_{2} \mathrm{~L}^{2}$ aroylhydrazones, a special type of Schiff bases, have been much less studied. In the present work, we report the synthesis and structures of two new vanadium(V) oxo complexes with general formula [VOL(bha)], where $\mathrm{L}=$ $\mathrm{L}^{1}=N^{\prime}$-(5-bromo-2-hydroxybenzylidene)-2-fluorobenzohydrazide $\left(\mathrm{H}_{2} \mathrm{~L}^{1}\right)$, and $\mathrm{L}=\mathrm{L}^{2}=N^{\prime}$-(3-bromo-2-hydroxybenzylidene)-2-fluorobenzohydrazide $\left(\mathrm{H}_{2} \mathrm{~L}^{2}\right)$.

\section{Experimental}

\section{1. Materials and Measurements}

Commercially available 5-bromosalicylaldehyde, 3bromosalicylaldehyde and 2-fluorobenzohydrazide were purchased from Aldrich and used without further purification. Other solvents and reagents were made in China and used as received. $\mathrm{C}, \mathrm{H}$ and $\mathrm{N}$ elemental analyses were performed with a Perkin-Elmer elemental analyser. Infrared spectra were recorded on a Nicolet AVATAR 360 spectrometer as $\mathrm{KBr}$ pellets in the $4000-400 \mathrm{~cm}^{-1}$ region. UV-Vis spectra were recorded on a Lambda 900 spectrometer. Thermal stability analysis was performed on a Perkin-Elmer Pyris Diamond TG-DTA thermal analyses system. ... 


\section{2. Synthesis of $H_{2} L^{1}$ and $H_{2} L^{2}$}

5-Bromosalicylaldehyde or 3-bromosalicylaldehyde $(1.0 \mathrm{mmol}, 0.20 \mathrm{~g})$ and 2-fluorobenzohydrazide (1.0 mmol, $0.15 \mathrm{~g})$ were dissolved in methanol $(30 \mathrm{~mL})$ with stirring. The mixture was stirred for about $30 \mathrm{~min}$ at room temperature to give clear solution. The solvent was evaporated to give colorless crystalline products. For $\mathrm{H}_{2} \mathrm{~L}^{1}$ : Yield, 93\%. Analysis: Found: C 49.73\%, H 3.12\%, N $8.40 \%$. Calculated for $\mathrm{C}_{14} \mathrm{H}_{10} \mathrm{BrFN}_{2} \mathrm{O}_{2}: \mathrm{C} 49.88 \%, \mathrm{H}$ $2.99 \%, \mathrm{~N} 8.31 \%$. For $\mathrm{H}_{2} \mathrm{~L}^{1}$ : Yield, $96 \%$. Analysis: Found: C $49.68 \%, \mathrm{H} 3.04 \%, \mathrm{~N} 8.43 \%$. Calculated for $\mathrm{C}_{14} \mathrm{H}_{10} \mathrm{Br}$ $\mathrm{FN}_{2} \mathrm{O}_{2}: \mathrm{C} 49.88 \%, \mathrm{H} 2.99 \%, \mathrm{~N} 8.31 \%$.

\subsection{Synthesis of the Complexes}

A methanolic solution $(10 \mathrm{~mL})$ of $\left[\mathrm{VO}(\mathrm{acac})_{2}\right](0.10$ mmol, $26.5 \mathrm{mg})$ was added to a methanolic solution (10 $\mathrm{mL})$ of $\mathrm{H}_{2} \mathrm{~L}(0.10 \mathrm{mmol}, 33.7 \mathrm{mg})$ and benzohydroxamic acid $(0.10 \mathrm{mmol}, 13.7 \mathrm{mg})$ with stirring. The mixture was stirred for $30 \mathrm{~min}$ at room temperature to give deep brown solution. The resulting solution was allowed to stand in air for a few days. Brown block-shaped crystals suitable for $\mathrm{X}$-ray single crystal diffraction were formed at the bottom of the vessel. The isolated products were washed three times with cold methanol, and dried in air. For $\left[\operatorname{VOL}^{1}(\mathrm{bha})\right]$ (1): Yield, 45\%. Analysis: Found: C 46.93\%, H 2.70\%, N 7.68\%. Calculated for $\mathrm{C}_{21} \mathrm{H}_{14} \mathrm{BrFN}_{3} \mathrm{O}_{5} \mathrm{~V}: \mathrm{C} 46.86 \%, \mathrm{H}$ $2.62 \%, \mathrm{~N} 7.81 \%$. For [VOL ${ }^{2}$ (bha)] (2): Yield, $53 \%$. Analysis: Found: C 46.72\%, H 2.71\%, N 7.73\%. Calculated for $\mathrm{C}_{21} \mathrm{H}_{14} \mathrm{BrFN}_{3} \mathrm{O}_{5} \mathrm{~V}$ : C 46.86\%, H 2.62\%, N 7.81\%.

\section{4. X-ray Crystallography}

Diffraction intensities for the complexes were collected at 298(2) K using a Bruker D8 VENTURE PHO-

Table 1. Crystallographic data and refinement parameters for the complexes

\begin{tabular}{lll}
\hline Chemical formula & \multicolumn{1}{c}{$\mathbf{1}$} & \multicolumn{2}{c}{$\mathbf{2}$} \\
\hline$M r$ & $\mathbf{C}_{\mathbf{2 1}} \mathbf{H}_{\mathbf{1 4}} \mathbf{B r F N}_{\mathbf{3}} \mathbf{O}_{\mathbf{5}} \mathbf{V}$ & $\mathbf{C}_{\mathbf{2 1}} \mathbf{H}_{\mathbf{1 4}} \mathbf{B r F N}_{\mathbf{3}} \mathbf{O}_{\mathbf{5}} \mathbf{V}$ \\
Crystal color, habit & 538.2 & 538.2 \\
Crystal size $\left(\mathrm{mm}^{3}\right)$ & Brown, block & Brown, block \\
Crystal system & $0.23 \times 0.23 \times 0.22$ & $0.32 \times 0.30 \times 0.27$ \\
Space group & Monoclinic & Monoclinic \\
$a(\AA)$ & $P 2_{1} / c$ & $C 2 / c$ \\
$b(\AA)$ & $10.0532(8)$ & $27.4352(19)$ \\
$c(\AA)$ & $17.2727(15)$ & $7.6107(5)$ \\
$\beta\left({ }^{\circ}\right)$ & $12.1902(10)$ & $20.9839(14)$ \\
V $\left(\AA^{3}\right)$ & $102.511(2)$ & $100.193(2)$ \\
$Z$ & $2066.5(3)$ & $4312.3(5)$ \\
$D_{\text {calc }}\left(\mathrm{g} \mathrm{cm}^{-3}\right)$ & 4 & 8 \\
Temperature $(\mathrm{K})$ & 1.730 & 1.658 \\
$\mu\left(\mathrm{mm}^{-1}\right)$ & $298(2)$ & $298(2)$ \\
$F(000)$ & 2.463 & 2.360 \\
Number of unique data & 3835 & 2144 \\
Number of observed & 2928 & 4003 \\
data $[I>2 \sigma(I)]$ & & 3256 \\
Number of parameters & 293 & \\
Number of restraints & 1 & 293 \\
$R_{1}, w R_{2}[I>2 \sigma(I)]$ & $0.0462,0.1213$ & $0.0385,0.0904$ \\
$R_{1}, w R_{2}($ all data $)$ & $0.0692,0.1366$ & $0.0530,0.0974$ \\
Goodness of fit on $F^{2}$ & 1.057 & 1.029 \\
\hline
\end{tabular}

Table 2. Selected bond distances $(\AA)$ and angles $\left(^{\circ}\right)$ for the complexes

\begin{tabular}{|c|c|c|c|}
\hline \multicolumn{4}{|l|}{1} \\
\hline$\overline{\mathrm{V}(1)-\mathrm{O}(1)}$ & $1.867(3)$ & $\mathrm{V}(1)-\mathrm{O}(2)$ & $1.950(3)$ \\
\hline $\mathrm{V}(1)-\mathrm{O}(3)$ & $2.185(3)$ & $\mathrm{V}(1)-\mathrm{O}(4)$ & $1.859(3)$ \\
\hline $\mathrm{V}(1)-\mathrm{O}(5)$ & $1.581(3)$ & $\mathrm{V}(1)-\mathrm{N}(1)$ & $2.079(3)$ \\
\hline $\mathrm{O}(5)-\mathrm{V}(1)-\mathrm{O}(4)$ & $97.28(14)$ & $\mathrm{O}(5)-\mathrm{V}(1)-\mathrm{O}(1)$ & $98.83(16)$ \\
\hline $\mathrm{O}(4)-\mathrm{V}(1)-\mathrm{O}(1)$ & $105.73(13)$ & $\mathrm{O}(5)-\mathrm{V}(1)-\mathrm{O}(2)$ & $98.85(15)$ \\
\hline $\mathrm{O}(4)-\mathrm{V}(1)-\mathrm{O}(2)$ & $90.54(12)$ & $\mathrm{O}(1)-\mathrm{V}(1)-\mathrm{O}(2)$ & $154.15(13)$ \\
\hline $\mathrm{O}(5)-\mathrm{V}(1)-\mathrm{N}(1)$ & $101.21(14)$ & $\mathrm{O}(4)-\mathrm{V}(1)-\mathrm{N}(1)$ & $157.66(13)$ \\
\hline $\mathrm{O}(1)-\mathrm{V}(1)-\mathrm{N}(1)$ & $83.80(13)$ & $\mathrm{O}(2)-\mathrm{V}(1)-\mathrm{N}(1)$ & $74.37(12)$ \\
\hline $\mathrm{O}(5)-\mathrm{V}(1)-\mathrm{O}(3)$ & $173.51(14)$ & $\mathrm{O}(4)-\mathrm{V}(1)-\mathrm{O}(3)$ & $76.37(11)$ \\
\hline $\mathrm{O}(1)-\mathrm{V}(1)-\mathrm{O}(3)$ & $84.34(12)$ & $\mathrm{O}(2)-\mathrm{V}(1)-\mathrm{O}(3)$ & $80.08(12)$ \\
\hline $\mathrm{N}(1)-\mathrm{V}(1)-\mathrm{O}(3)$ & $84.72(11)$ & & \\
\hline \multicolumn{4}{|l|}{2} \\
\hline$\overline{\mathrm{V}(1)-\mathrm{O}(1)}$ & $1.870(2)$ & $\mathrm{V}(1)-\mathrm{O}(2)$ & $1.9410(19)$ \\
\hline $\mathrm{V}(1)-\mathrm{O}(3)$ & $2.192(2)$ & $\mathrm{V}(1)-\mathrm{O}(4)$ & $1.8564(19)$ \\
\hline $\mathrm{V}(1)-\mathrm{O}(5)$ & $1.587(2)$ & $\mathrm{V}(1)-\mathrm{N}(1)$ & $2.061(2)$ \\
\hline $\mathrm{O}(5)-\mathrm{V}(1)-\mathrm{O}(4)$ & $95.47(10)$ & $\mathrm{O}(5)-\mathrm{V}(1)-\mathrm{O}(1)$ & $98.17(11)$ \\
\hline $\mathrm{O}(4)-\mathrm{V}(1)-\mathrm{O}(1)$ & $106.70(9)$ & $\mathrm{O}(5)-\mathrm{V}(1)-\mathrm{O}(2)$ & $102.00(10)$ \\
\hline $\mathrm{O}(4)-\mathrm{V}(1)-\mathrm{O}(2)$ & $90.45(8)$ & $\mathrm{O}(1)-\mathrm{V}(1)-\mathrm{O}(2)$ & $152.09(9)$ \\
\hline $\mathrm{O}(5)-\mathrm{V}(1)-\mathrm{N}(1)$ & $98.15(10)$ & $\mathrm{O}(4)-\mathrm{V}(1)-\mathrm{N}(1)$ & 161.31(9) \\
\hline $\mathrm{O}(1)-\mathrm{V}(1)-\mathrm{N}(1)$ & $84.00(9)$ & $\mathrm{O}(2)-\mathrm{V}(1)-\mathrm{N}(1)$ & $74.26(8)$ \\
\hline $\mathrm{O}(5)-\mathrm{V}(1)-\mathrm{O}(3)$ & $170.98(9)$ & $\mathrm{O}(4)-\mathrm{V}(1)-\mathrm{O}(3)$ & $75.97(8)$ \\
\hline $\mathrm{O}(1)-\mathrm{V}(1)-\mathrm{O}(3)$ & $81.88(9)$ & $\mathrm{O}(2)-\mathrm{V}(1)-\mathrm{O}(3)$ & $81.18(8)$ \\
\hline $\mathrm{N}(1)-\mathrm{V}(1)-\mathrm{O}(3)$ & $90.83(8)$ & & \\
\hline
\end{tabular}
$\cdots$ 
TON diffractometer with Mo $\mathrm{K} \alpha$ radiation $(\lambda=0.71073$ $\AA$ ). The collected data were reduced using SAINT program, ${ }^{7}$ and multi-scan absorption corrections were performed using SADABS program. ${ }^{8}$ Structures of the complexes were solved by direct methods and refined against $F^{2}$ by full-matrix least-squares methods using SHELXTL. ${ }^{9}$ All of the non-hydrogen atoms were refined anisotropically. The amino $\mathrm{H}$ atoms in both structures were located from difference Fourier maps and refined isotropically, with N-H distances restrained to $0.90(1) \AA$. The remaining $\mathrm{H}$ atoms were placed in idealized positions and constrained to ride on their parent atoms. Crystallographic data for the complexes are summarized in Table 1. Selected bond lengths and angles are given in Table 2 .

\section{Results and Discussion}

\section{1. General}

Replacement of two acetylacetonate ligands in $\left[\mathrm{VO}(\mathrm{acac})_{2}\right]$ by aroylhydrazone ligands and benzohydroxamate ligands in methanol resulted in the formation of two isomeric structures. In both complexes, the dinegative aroylhydrazone ligands are coordinated to $\mathrm{VO}$ cores via phenolate $\mathrm{O}$, imino $\mathrm{N}$, and enolate $\mathrm{O}$ atoms, and the mono-negative aroylhydroxamate ligand coordinated to the VO cores via deprotonated hydroxyl $\mathrm{O}$ atom and carbonyl $\mathrm{O}$ atom. The complexes are soluble in DMF, DMSO, methanol, ethanol, and acetonitrile. Molar conductance of complexes $\mathbf{1}$ and $\mathbf{2}$ at concentration of $10^{-4} \mathrm{M}$ are 17 and $20 \Omega^{-1} \mathrm{~cm}^{2} \mathrm{~mol}^{-1}$, respectively, indicating they are nonelectrolytes.

\section{2. Crystal Structure Description of the Complexes}

The molecular structures and atom numbering schemes of complexes $\mathbf{1}$ and $\mathbf{2}$ are shown in Figures 1 and 2, respectively. The coordination geometry around each $\mathrm{V}$ atom is highly distorted octahedral. In each complex, the aroylhydrazone ligand behaves in a tridentate manner in which the phenolate $\mathrm{O}$, imino $\mathrm{N}$, and enolate $\mathrm{O}$ atoms occupy a meridional plane. The benzohydroxamate ligand behaves in a bidentate manner, and coordinates to the $\mathrm{V}$ atom through the deprotonated hydroxyl $\mathrm{O}$ atom and the carbonyl $\mathrm{O}$ atom. The equatorial plane of each octahedral coordination is defined by $\mathrm{O}(1), \mathrm{N}(1), \mathrm{O}(2)$, and $\mathrm{O}(4)$ atoms, and the axial positions are occupied by $\mathrm{O}(3)$ and $\mathrm{O}(5)$ atoms. The octahedral geometries are much deviated, as evidenced by the corresponding bond lengths and angles. The $\mathrm{V}(1)-\mathrm{O}(3)$ bonds are significantly longer than the other $\mathrm{V}-\mathrm{O}$ bonds, yet, it is not uncommon for such complexes. ${ }^{10}$ Atoms $\mathrm{O}(1), \mathrm{O}(2), \mathrm{N}(1)$, and $\mathrm{O}(4)$ in both complexes that define a plane show high degree of planarity, with the $\mathrm{V}$ atoms displaced by $0.297(1) \AA$ for $\mathbf{1}$ and $0.273(1) \AA$ for 2 toward the axial oxo groups. All bond

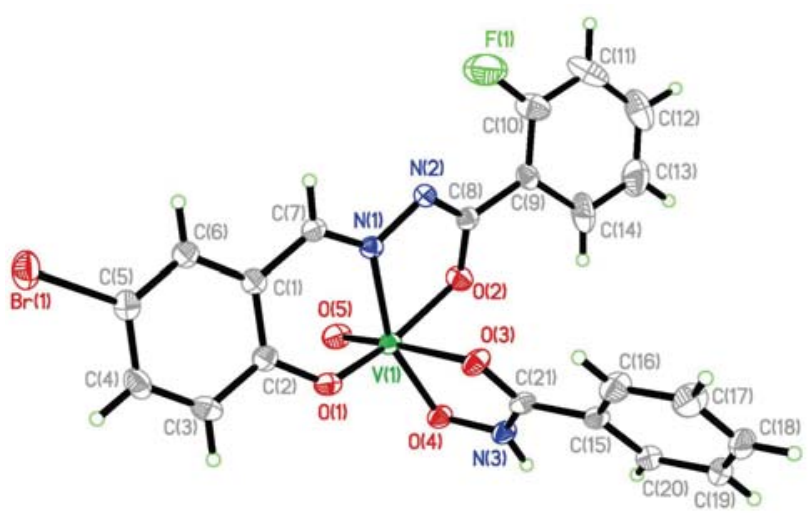

Figure 1. ORTEP plot of the crystal structure of 1. Displacement ellipsoids of non-hydrogen atoms are drawn at the $30 \%$ probability level.

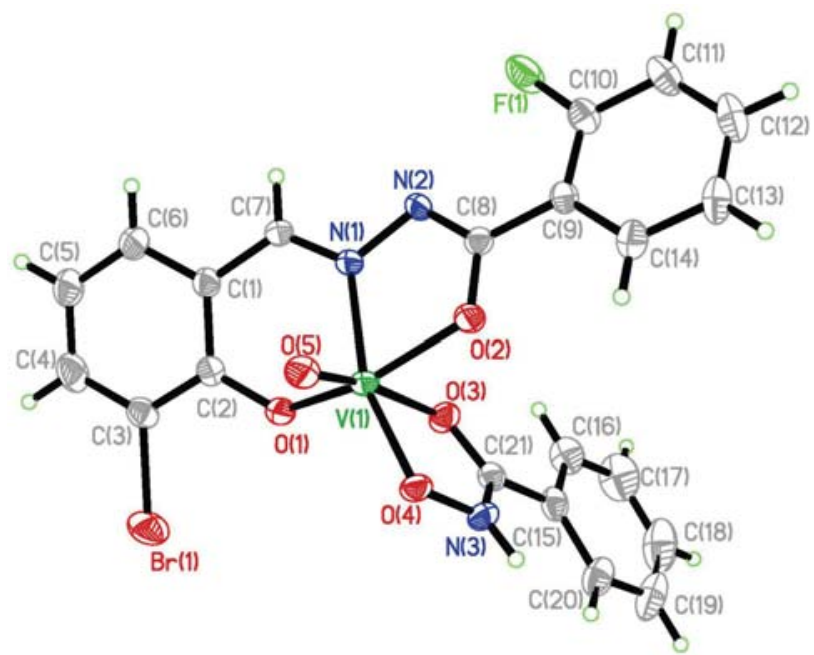

Figure 2. ORTEP plot of the crystal structure of 2. Displacement ellipsoids of non-hydrogen atoms are drawn at the $30 \%$ probability level.

lengths in the complexes are almost equal within the standard deviations, and comparable to those observed in similar vanadium $(\mathrm{V})$ complexes. ${ }^{10}$ The angular distortion in the octahedral environment around $\mathrm{V}$ comes from the fiveand six-membered chelate rings taken by the aroylhydrazone ligands. For the same reason, the trans angles significantly deviate from the ideal values of $180^{\circ}$. The benzohydrazone ligand in $\mathbf{1}$ is approximately planar, with dihedral angle between the benzene rings of $3.7(3)^{\circ}$, while that in $\mathbf{2}$ is much twisted, with dihedral angle of $25.5(5)^{\circ}$.

In the crystal structure of $\mathbf{1}$ (Figure 3), molecules are linked through intermolecular $\mathrm{N}-\mathrm{H} \cdots \mathrm{N}$ hydrogen bonds $\left[\mathrm{N}(3)-\mathrm{H}(3)=0.90(1) \AA, \mathrm{H}(3) \cdots \mathrm{N}(2)^{\mathrm{i}}=2.11(1) \AA\right.$, $\mathrm{N}(3) \cdots \mathrm{N}(2)^{\mathrm{i}}=3.005(5) \AA, \mathrm{N}(3)-\mathrm{H}(3) \cdots \mathrm{N}(2)^{\mathrm{i}}=172(4)^{\circ}$; symmetry code for $\mathrm{i}: x, 3 / 2-y,-1 / 2+z$ ], to form $1 \mathrm{D}$ chains running down the $c$ axis. In the crystal structure of 2 (Figure 4), molecules are linked through intermolecular $\mathrm{N}(3)-\mathrm{H}(3) \cdots \mathrm{N}(2)$ and $\mathrm{N}(3)-\mathrm{H}(3) \cdots \mathrm{F}(1)$ hydrogen bonds 


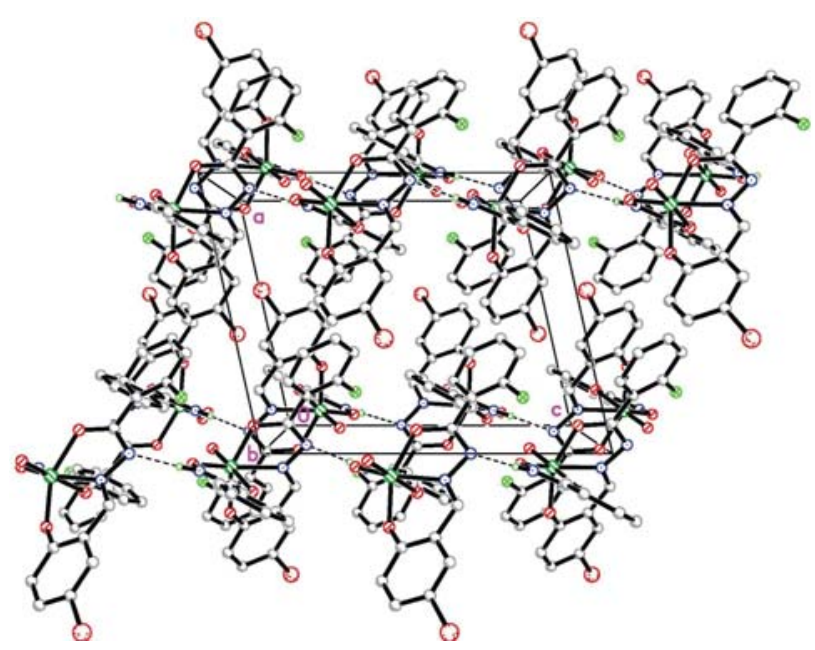

Figure 3. Packing of molecules for compound 1. Hydrogen bonds are shown as dashed lines.

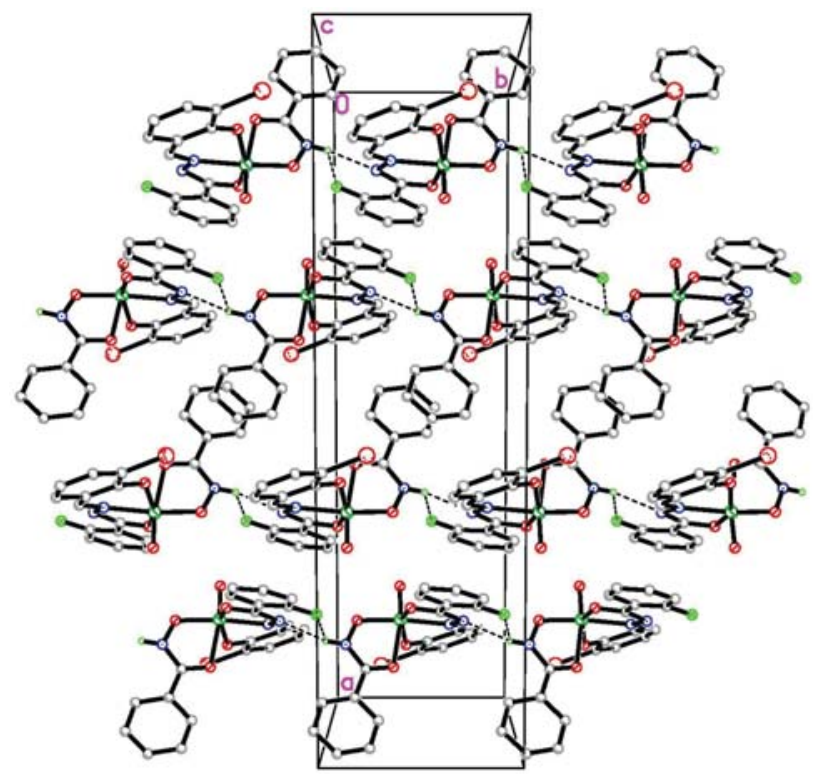

Figure 4. Packing of molecules for compound 2. Hydrogen bonds are shown as dashed lines.

$\left[\mathrm{N}(3)-\mathrm{H}(3)=0.90(1) \AA, \mathrm{H}(3) \cdots \mathrm{N}(2)^{\mathrm{ii}}=2.10(2) \AA\right.$, $\mathrm{N}(3) \cdots \mathrm{N}(2)^{\mathrm{ii}}=2.915(3) \AA, \mathrm{N}(3)-\mathrm{H}(3) \cdots \mathrm{N}(2)^{\mathrm{ii}}=150(3)^{\circ}$; $\mathrm{N}(3)-\mathrm{H}(3)=0.90(1) \AA, \mathrm{H}(3) \cdots \mathrm{F}(1)^{\mathrm{ii}}=2.29(3) \AA$, $\mathrm{N}(3) \cdots \mathrm{F}(1)^{\mathrm{ii}}=2.866(3) \AA, \mathrm{N}(3)-\mathrm{H}(3) \cdots \mathrm{F}(1)^{\mathrm{ii}}=122(2)^{\circ}$; symmetry code for ii: $x,-1+y, z$ ], to form $1 \mathrm{D}$ chains running down the $b$ axis. There are no other obvious weak interactions among the molecules of the complexes.

\section{3. IR and UV-Vis Spectra}

The arolhydrazone ligands showed stretching bands attributed to $\mathrm{C}=\mathrm{O}, \mathrm{C}=\mathrm{N}, \mathrm{C}-\mathrm{OH}$ and $\mathrm{NH}$ at about 1655 , 1635,1155 and 1238, and $3245 \mathrm{~cm}^{-1}$, respectively. Both complexes exhibit typical bands at about 973 and 977 $\mathrm{cm}^{-1}$, assigned to $\mathrm{V}=\mathrm{O}$ vibration. The bands due to $\mathrm{v}_{\mathrm{C}=\mathrm{O}}$ and $\mathrm{v}_{\mathrm{NH}}$ were absent in the complexes, but new $\mathrm{C}-\mathrm{O}$ stretches appeared at $1275 \mathrm{~cm}^{-1}$ for $\mathbf{1}$ and $1282 \mathrm{~cm}^{-1}$ for $\mathbf{2}$. This suggests occurrence of keto-enol of the ligands during complexation. The $v_{\mathrm{C}=\mathrm{N}}$ absorption observed at about $1635 \mathrm{~cm}^{-1}$ in the free aroylhydrazone ligands shifted to $1605 \mathrm{~cm}^{-1}$ for 1 and $1600 \mathrm{~cm}^{-1}$ for 2 upon coordination to $\mathrm{V}$ atoms. The weak peaks in low wave numbers in the region $400-600 \mathrm{~cm}^{-1}$ may be attributed to $\mathrm{V}-\mathrm{O}$ and $\mathrm{V}-\mathrm{N}$ bonds in the complexes.

The acetonitrile solutions of the complexes with concentration of $10^{-5} \mathrm{~mol} \cdot \mathrm{L}^{-1}$ have been used to record the electronic spectra. The main features of all the spectra are quite similar (Figures 5 and 6). There are absorptions within the range $500-380 \mathrm{~nm}$ in the complexes. This can be attributed to the ligand-to-metal charge transfer transitions (LMCT). The high energy absorptions in the range $310-380 \mathrm{~nm}$ are most likely due to the transition involving ligand orbitals only.

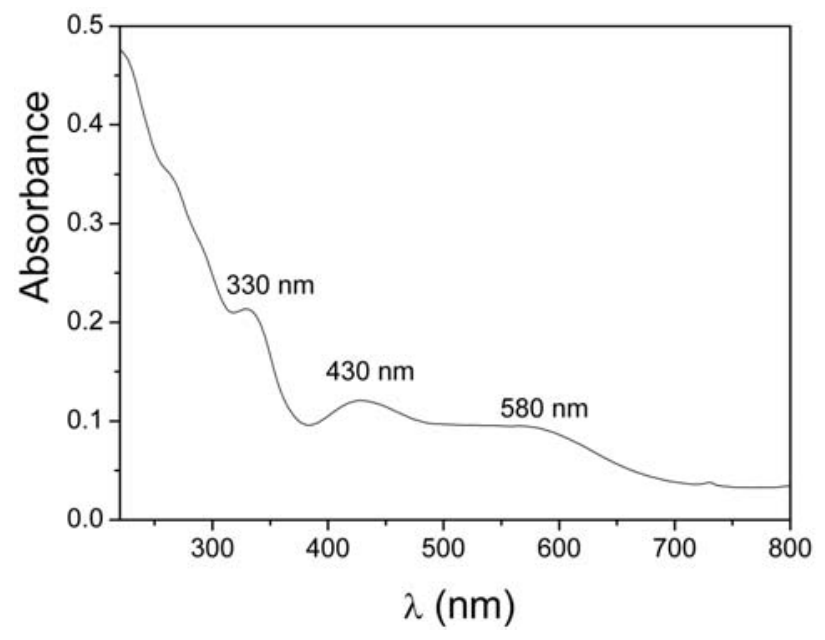

Figure 5. UV-vis spectrum of complex 1.

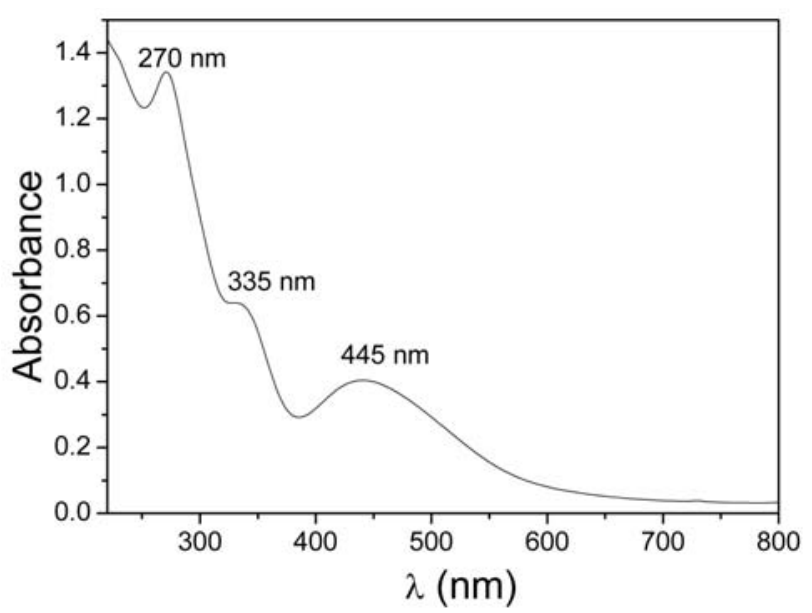

Figure 6. UV-vis spectrum of complex 2. 


\section{4. Thermal Property}

Differential thermal (DT) and thermal gravimetric analyses (TGA) were conducted to examine the stability of the complexes (Figure 7 for $\mathbf{1}$ and Figure 8 for $\mathbf{2}$ ). For $\mathbf{1}$, the first step started at $120^{\circ} \mathrm{C}$ and ended at $130{ }^{\circ} \mathrm{C}$, with a weight loss of $3 \%$, might be caused by the loss of the cohesive solvent. Actually, the complex was first decomposed from $205{ }^{\circ} \mathrm{C}$ and completed at $520{ }^{\circ} \mathrm{C}$, corresponding to the loss of the ligands and formation of $\mathrm{V}_{2} \mathrm{O}_{5}$. The observed weight loss of $82.2 \%$ is close to the calculated value of $83.1 \%$. For 2 , it was first decomposed from $165^{\circ} \mathrm{C}$ and completed at $490{ }^{\circ} \mathrm{C}$, corresponding to the loss of the ligands and formation of $\mathrm{V}_{2} \mathrm{O}_{5}$. The observed weight loss of $81.9 \%$ is close to the calculated value of $83.1 \%$.

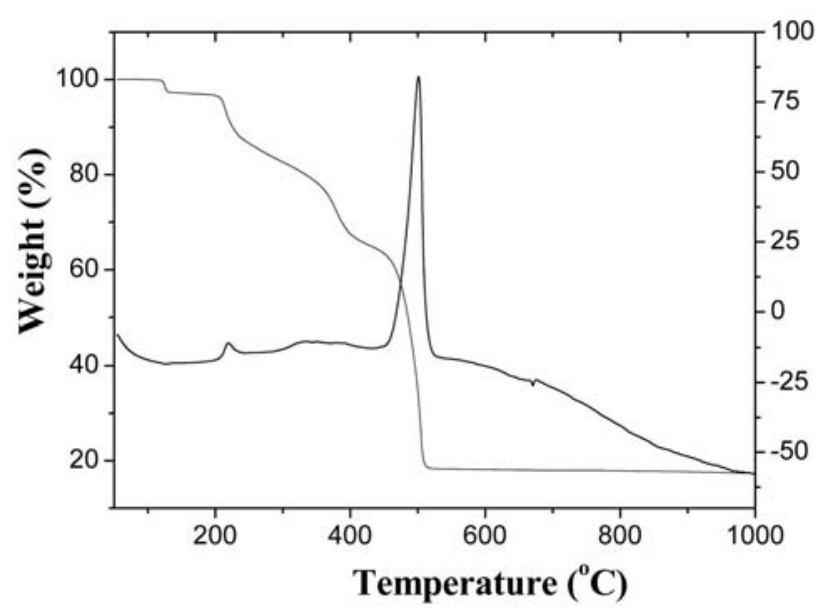

Figure 7. DT-TGA curve of $\mathbf{1}$.

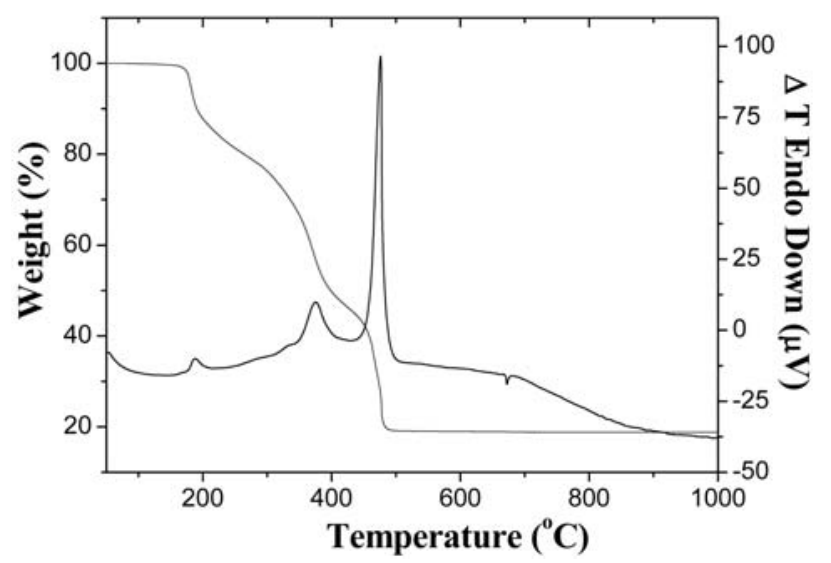

Figure 8. DT-TGA curve of 2.

\section{Conclusion}

In summary, two aroylhydroxamate-coordinated mononuclear vanadium(V) oxo complexes with similar benzohydrazone ligands have been prepared and structu- rally characterized by single crystal $\mathrm{X}$-ray diffraction, as well as elemental analysis and FT-IR and UV-Vis spectra. The aroylhydrazone ligands coordinate to the $\mathrm{V}$ atoms through the phenoalte $\mathrm{O}$, imino $\mathrm{N}$, and enolate $\mathrm{O}$ atoms. Thermal stability of the complexes has also been studied, and the final product is $\mathrm{V}_{2} \mathrm{O}_{5}$.

\section{Supplementary Information}

CCDC-967486 (1) and 967487 (2) contain the supplementary crystallographic data for this paper. These data can be obtained free of charge at http://www.ccdc. cam.ac.uk/const/retrieving.html or from the Cambridge Crystallographic Data Centre (CCDC), 12 Union Road, Cambridge CB2 1EZ, UK; fax: +44(0)1223-336033 or e-mail: deposit@ccdc.cam.ac.uk.

\section{References}

1. (a) M. Noji, T. Kobayashi, Y. Uechi, A. Kikuchi, H. Kondo, S. Sugiyama, K. Ishii, J. Org. Chem. 2015, 80, 3203-3210;

(b) M. Pradhan, A. Roy, A. K. Sinha, R. Sahoo, D. Deb, T. Pal, Dalton Trans. 2015, 44, 1889-1899; http://dx.doi.org/10.1039/C4DT02863E

(c) I. Correia, P. Adao, S. Roy, M. Wahba, C. Matos, M. R. Maurya, F. Marques, F. R. Pavan, C. Q. F. Leite, F. Avecilla, J. C. Pessoa, J. Inorg. Biochem. 2014, 141, 83-93;

(d) R. S. Nair, M. Kuriakose, V. Somasundaram, V. Shenoi, M. R. P. Kurup, P. Srinivas, Life Sci. 2014, 116, 90-97;

(e) D. Qu, F. Niu, Z. Zhao, K.-X. Yan, Y.-T. Ye, J. Wang, M. Zhang, Z. You, Bioorg. Med. Chem. 2015, 23, 1944-1949; (f) J.-Q. Ren, Q.-Z. Jiao, Y.-N. Wang, F.-Y. Xu, X.-S. Cheng, Z.-L. You, Chinese J. Inorg. Chem. 2014, 30, 640-648.

2. (a) U. Ashiq, R. Ara, M. Mahroof-Tahir, Z. T. Maqsood, K. M. Khan, S. N. Khan, H. Siddiqui, M. I. Choudhary, Chem. Biodivers. 2008, 5, 82-92;

(b) O. Bortolini, V. Conte, J. Inorg. Biochem. 2005, 99, 1549-1557;

http://dx.doi.org/10.1016/j.jinorgbio.2005.04.003

(c) V. Monga, K. H. Thompson, V. G. Yuen, V. Sharma, B. O. Patrick, J. H. McNeill, C. Orvig, Inorg. Chem. 2005, 44, 2678-2688; http://dx.doi.org/10.1021/ic0486926

(d) D. C. Crans, J. J. Smee, E. Gaidamauskas, L. Q. Yang, Chem. Rev. 2004, 104, 849-902.

http://dx.doi.org/10.1021/cr020607t

3. (a) B. D. Liboiron, K. H. Thompson, G. R. Hanson, E. Lam, N. Aebischer, C. Orvig, J. Am. Chem. Soc. 2005, 127, 5104-5115; http://dx.doi.org/10.1021/ja043944n

(b) H. H. Monfared, S. Kheirabadi, N. A. Lalami, P. Mayer, Polyhedron 2011, 30, 1375-1384; http://dx.doi.org/10.1016/j.poly.2011.02.005

(c) T. Kumar, M. G. B. Drew, K. K. Mukherjea, Polyhedron 2011, 30, 2286-2293;

http://dx.doi.org/10.1016/j.poly.2011.06.005 $\ldots$ 
(d) S. Farhadi, M. Taherimehr, Acta Chim. Slov. 2008, 55, 637-643;

(e) J. A. L. Da Silva, J. J. R. F. Da Silva, A. J. L. Pombeiro, Coord. Chem. Rev. 2011, 255, 2232- 2248.

http://dx.doi.org/10.1016/j.ccr.2011.05.009

4. (a) M. D. Altintop, A. Ozdemir, G. Turan-Zitouni, S. Ilgin, O. Atli, G. Iscan, Z. A. Kaplancikli, Eur. J. Med. Chem. 2012, 58, 299-307;

http://dx.doi.org/10.1016/j.ejmech.2012.10.011

(b) M. Alagesan, N. S. P. Bhuvanesh, N. Dharmaraj, Dalton Trans. 2013, 42, 7210-7223;

http://dx.doi.org/10.1039/c3dt50371b

(c) Z. A. Kaplancikli, M. D. Altintop, A. Ozdemir, G. TuranZitouni, S. I. Khan, N. Tabanca, Lett. Drug Des. Discov. 2012, 9, 310-315. http://dx.doi.org/10.2174/157018012799129828

5. (a) M. Rubcic, D. Milic, B. Kamenar, M. Cindric, Acta Chim. Slov. 2008, 55, 810-814;

(b) A. Datta, P.-H. Liu, J.-H. Huang, E. Garribba, M. Turnbull, B. Machura, C.-L. Hsu, W.-T. Chang, A. Pevec, Polyhedron 2012, 44, 77-87; http://dx.doi.org/10.1016/j.poly.2012.06.027

(c) V. P. Singh, S. Singh, D. P. Singh, P. Singh, K. Tiwari, M. Mishra, R. J. Butcher, Polyhedron 2013, 56, 71-81; http://dx.doi.org/10.1016/j.poly.2013.03.048

(d) S. Mukerjee, S. Chowdhury, A. Ghorai, U. Ghosh, H. Stoeckli-Evans, Polyhedron 2013, 51, 228-234.

http://dx.doi.org/10.1016/j.poly.2013.01.002
6. (a) S. I. Pillai, S. P. Subramanian, M. Kandaswamy, Eur. J. Med. Chem. 2013, 63, 109-117;

http://dx.doi.org/10.1016/j.ejmech.2013.02.002

(b) D. C. Crans, A. M. Trujillo, P. S. Pharazyn, M. D. Cohen, Coord. Chem. Rev. 2011, 255, 2178-2192; http://dx.doi.org/10.1016/j.ccr.2011.01.032

(c) M. N. Islam, A. A. Kumbhar, A. S. Kumbhar, M. Zeller, R. J. Butcher, M. B. Dusane, B. N. Joshi, Inorg. Chem. 2010, 49, 8237-8246; http://dx.doi.org/10.1021/ic9025359

(d) D. Sanna, G. Micera, E. Garribba, Inorg. Chem. 2010, 49, 174-187. http://dx.doi.org/10.1021/ic9017213

7. Bruker, SMART and SAINT. Bruker AXS Inc., Madison, Wisconsin, USA, 2002.

8. G. M. Sheldrick, SADABS. Program for Empirical Absorption Correction of Area Detector, University of Göttingen, Germany, 1996.

9. G. M. Sheldrick, Acta Crystallogr. 2008, A64, 112-122. http://dx.doi.org/10.1107/S0108767307043930

10. (a) S. Gao, Z.-Q. Weng, S.-X. Liu, Polyhedron 1998, 17, 3595-3606; http://dx.doi.org/10.1016/S0277-5387(98)00154-5

(b) M. R. Maurya, S. Khurana, C. Schulzke, D. Rehder, Eur. J. Inorg. Chem. 2001, 3, 779-788;

http://dx.doi.org/10.1002/1099-0682(200103)2001:3 <779::AID-EJIC779>3.0.CO;2-\#

(c) S. Nica, M. Rudolph, H. Gorls, W. Plass, Inorg. Chim. Acta 2007, 360, 1743-1752;

http://dx.doi.org/10.1016/j.ica.2006.09.018

(d) K.-H. Yang, Acta Chim. Slov. 2014, 61, 629-636.

\section{Povzetek}

Pri reakciji $\left[\mathrm{VO}(\mathrm{acac})_{2}\right]($ acac $=$ acetilacetonat $) \mathrm{z}$ benzohidroksamsko kislino $($ Hbha $)$ in dvema sorodnima aroilhidrazonskima ligandoma $\mathrm{v}$ metanolu nastaneta dva enojedrna vanadijeva(V) okso benzohidroksamatna kompleksa s splošno formulo [VOL(bha)], kjer je $\mathrm{L}=\mathrm{L}^{1}=N^{\prime}$-(5-bromo-2-hidroksibenziliden)-2-fluorobenzohidrazid $\left(\mathrm{H}_{2} \mathrm{~L}^{1}\right)$, in $\mathrm{L}=\mathrm{L}^{2}=N^{\prime}$ (3-bromo-2-hidroksibenziliden)-2-fluorobenzohidrazid $\left(\mathrm{H}_{2} \mathrm{~L}^{2}\right)$. Kristalna in molekulska struktura kompleksov je bila določena $\mathrm{z}$ rentgensko monokristalno difrakcijo. Obe proučevani spojini sta bili nadalje okarakterizirani z elementno analizo ter FT-IR in UV-Vis spektroskopijo. Rentgenska monokristalna analiza je pokazala, da sta V atoma v obeh kompleksih oktaedrično koordinirana $\mathrm{z}$ benzohidrazonskim ligandom, ki je na VO skupino vezan preko fenolatnega $\mathrm{O}$, iminskega $\mathrm{N}$ in enolatnega $\mathrm{O}$ atoma, ter $\mathrm{z}$ benzohidroksamatnim ligandom, ki je na VO skupino vezan preko deprotoniranega hidroksidnega $\mathrm{O}$ in karbonilnega $\mathrm{O}$ atoma. Študirana je bila termična stabilnost obeh kompleksov. 